\title{
Урянхай и урянхайцы. Проблема поисков локуса и этносов"
}

\author{
Алексей А. Бурыкин \\ Калмыцкий научный центр Российской академии наук, Российская Федерация
}

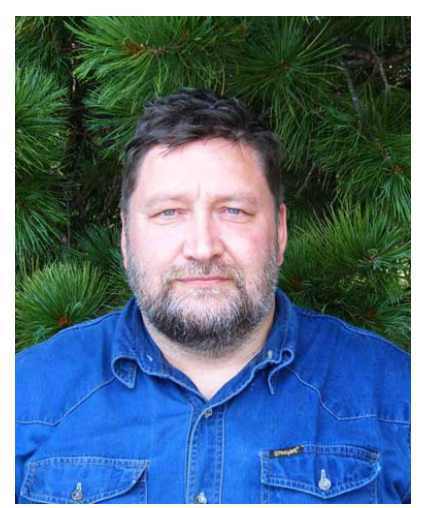

Статья посвящена проблеме наименований местности Урянхай и этнонима урянхайцы, занимавших значительное место в древней и новой истории Центральной Азии. Как известно, Тува в русской научной литературе именовалась Урянхайский край, а тувинцы - урянхайцами. Эти названия, известные еще по средневековым источникам по истории тюркских и монгольских народов и широко распространившиеся в географическом отношении далеко в Забайкалье до территории Дальнего Востока, до сих пор не имели даже сколько-нибудь правдоподобного объяснения. Не была ясна и языковая принадлежность наименования местности (историко-географической провинции) Урянхай, и можно было только догадываться, что живущий там этнос и небольшие этнические группы получили свое название по месту проживания. Использование в якутском фольклоре названия (по существу фольклорного самоназвания) ураангхай-сахалар связывает поставленные вопросы с проблемой этногенеза и этнической истории якутов и с этнической историей народов окрестностей озера Байкал.

Автор собрал топонимические параллели для географического имени Урянхай. Среди них: Уренгой - название реки в истоках Оби или Иртыша, отмеченное в дневнике путешествия Н. Г. Спафария 1675 г., Новый Уренгой - название города в низовьях Оби. Объяснение происхождения этих топонимов найдено на материале самодийских языков: на ненецком языке варё-нг-хой - «гора с проталинами, гора, на которой раньше всего тает снег». Такой осложненный географический апеллятив закрепился в качестве конкретного топонима лишь в некоторых местах, и, учитывая горный рельеф территории Тувы, закрепился как название территории в целом. Название «урянхайцы», которое не могло быть самоназванием ни одного из народов Тувы, распространилось, по-видимому, в связи с миграциями тюркоязычных народов в Прибайкалье и Забайкалье, а также на Дальний Восток. Вероятно, предки якутов принесли название Ураангкай как часть самоназвания из районов Прибайкалья, соседствующих с территорией Тувы, но, возможно, что наименование ураангхай-саха является благоприобретенной особенностью языка якутского фольклора, не связанной с дискуссионными проблемами этнической истории якутов.

Ключевые слова: Тува; топонимия; языковые контакты; тувинский язык; тофаларский язык; ненецкий язык; самодийские языки, Якутия, якутский язык, якутский фольклор, эвенкийский язык; Урянхай; урянхайцы

"Исследование проведено в рамках государственной субсидии - проект «Устное и письменное наследие монгольских народов России, Монголии и Китая: трансграничные традиции и взаимодействия» (регистрационный номер АААA-А19-119011490036-1).

\section{Для цитирования:}

Бурыкин А. А. Урянхай и урянхайцы. Проблема поисков локуса и этносов [Электронный ресурс] // Новые исследования Тувы. 2019, № 2. URL: https://nit.tuva.asia/nit/article/view/857 (дата обращения: дд.мм.гг.). DOI: 10.25178/ nit.2019.2.17

Бурыкин Алексей Алексеевич - доктор филологических наук, доктор исторических наук, ведущий научный сотрудник отдела монгольской филологии Калмыцкого научного центра РАН. Адрес: Адрес: 358000, Россия, г. Элиста, ул. Илишкина, д. 8. Тел.: +7 (911) 709-14-76. Эл. адрес: albury@mail.ru

Burykin Aleksey Alekseevich, Doctor of Philology, Doctor of History, Leading Research Fellow, Department of Mongolian Philology, Kalmyk Scientific Center of the Russian Academy of Sciences. Postal address: 8 Ilishkin St., 358000 Elista, Russian Federation. Tel.: +7 (911) 709-14-76. E-mail: albury@mail.ru 


\title{
Uriankhai and Uriankhaians: finding the locus and ethnic groups"
}

\author{
Aleksey A. Burykin \\ Kalmyk Scientific Center of the Russian Academy of Sciences, \\ Russian Federation
}

\begin{abstract}
The article is devoted to the problem of the names of the placename of Uriankhai and the ethnonym Uriankhai people, who played an important part in the ancient and early modern history of Central Asia. Russian researchers are well known to have referred to Tuva as Uriankhai Krai, and called Tuvans the Uriankhai. These names, found as early as in medieval sources on the history of Turkic and Mongolian peoples and widely distributed geographically from the Transbaikalia up to the Far East, have yet resisted any plausible etymological explanation. The linguistic identity of the name of the locality of Uriankhai as a historical and geographical region was also unclear, and one could only infer by guesswork that both the main ethnicity in the region and smaller ethnic groups got their name from their area of residence. The use of the name (essentially a folk endonym) UraangkhaiSakhalar in Yakut folklore links these problems to the issues of ethnogenesis and ethnic history of the Yakuts and with the ethnic history of the peoples of the Baikal environs.

The author, in his search for toponymic parallels for the geographical name Uriankhai, focused on Urengoy - the name of the river in the headwaters of the Ob or Irtysh, noted in the travel diary of N.G. Spathari (Spafarius) in 1675, and Novy Urengoy - the name of the city in the lower reaches of the Ob. An explanation of the origin of these toponyms has been found in Samoyed languages: in Nenets, 'varyo-ng-hoi' means "a mountain with thawed patches, a mountain on which snow melts before everywhere else". Such a complicated geographical appellate entrenched as a specific toponym only in some places, and, taking into account the mountainous terrain of the territory of Tuva, it was fixed as the name of the territory as a whole. The name "Uriankhaians", which could not be the self-name of any of the peoples of Tuva, has apparently spread in connection with the migrations of the Turkic-speaking peoples in the Baikal and Transbaikalia, as well as to the Far East. Probably, the ancestors of the Yakuts brought the name Uraangkai as part of the self-name from the regions of the Baikal region adjacent to the territory of Tuva, but it is possible that the name Uraangkhai-Sakha is an acquired feature of the language of Yakut folklore, not related to the debatable problems of the Yakut ethnic history.
\end{abstract}

Keywords: Tuva; toponymy; linguistic contacts; Tuvan language; Tofalar language; Nenets language; Samoyed languages, Yakutia, Yakut language, Yakut folklore, Evenki language

"The study was carried out within the framework of state subsidies - the project "Oral and Written Heritage of the Mongolian Peoples of Russia, Mongolia and China: Cross-Border Traditions and Interactions” (registration number AAAA-A19-119011490036-1).

\section{For citation}

Burykin A. A. Uriankhai and Uriankhaians: finding the locus and ethnic groups. The New Research of Tuva. 2019, № 2. URL: https://nit.tuva.asia/nit/article/view/857 (access date ...). DOI: 10.25178/nit.2019.2.17

\section{Введение}

Понятия и термины «Урянхай» как указание на какую-то местность и территорию, и «урянхайцы» как население территории, называемой по приведенному выше названию, давно стали ключевыми элементами истории целого ряда народов Центральной Азии. В наибольшей мере эти понятия связаны с территорией и населением Тувы (Кузьмин, 2018: 2-3), и понятно влияние названия «Урянхайский край» на решение проблем исторической географии Центральной Азии и формирование представлений об этнической истории этого региона. Связь истории урянхайцев, известных нам по письменным источникам и фольклорным данным, оказывается важной не только для тувинцев и монголоязычных народов, но в той или иной степени для бурят и особенно для якутов, у которых в их собственной исторической традиции, основанной преимущественно на фольклорных данных, стало привычным рассматривать этноним урянхай как древнее название якутского народа. Не вполне понятно, по какой причине этническое наименование урянхай стало связываться с народами тунгусской группы, чаще всего с эвенками, и каковы основания для того, чтобы для решения проблемы этнического состава территории в прошлом можно было доверять фольклорным данным без поддержки иными историко-этнографическими источниками. 
НОВЫЕ ИССЛЕДОВАНИЯ ТУВЫ

www.nit.tuva.asia

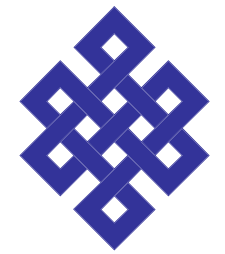

\section{THE NEW RESEARCH OF TUVA}

Novye issledovaniia Tuvy

Один из главных вопросов, от которого будет зависеть направление поисков и характер решения поставленных проблем - это языковая принадлежность и этимология топонимического именования Урянхай - мы пока на основе имеющихся в литературе материалов не можем, да и не сможем определить локализацию этого источникового топонима. По опыту источниковедческого изучения связи этнонимов и топонимов, имеющих одну и ту же основу, мы можем быть уверены в том, что названия этнических групп обычно образовывались от топонимов, то есть в данном случае от названий мест, где проживали данные этнические группы - разумеется, в большинстве таких случаев речь шла об аллоэтнонимах, названиях народов, бытующих в иной этноязыковой среде, хотя количество исключений, когда топоним (чаще всего гидроним) образовывался от самоназвания какой-либо этнической группы народа, трудноопределимо.

\section{Из истории вопроса}

В анонимном предисловии к первому изданию знаменитого труда Г. В. Ксенофонтова (о нем см.: Дьячкова, 1999; 2000; Романова, 2003) «Ураангхай-сахалар», вышедшему в 1937 г., автор его пишет: «Основываясь на этих данных, Ксенофонтов высказывает гипотезу, что как северные якуты-оленеводы, так и основное ядро вилюйских якутов-скотоводов по своему этническому происхождению не были турками. Всю эту группу автор объединяет под названием якутов-урянхайцев, усматривая в этом этническом термине позднейшую лингвистическую метаморфозу имени орочон (орончон) с переходными формами орон-кон, уран-кан, урааныкаан. При таком предположении, якуты-урянхайцы образовались из отуреченных тунгусских племен Манчжурии, Амура, Прибайкалья и самой Лены. В их составе автор предполагает небольшую примесь западных монголов-ойратов, в числе которых были и предки современных северобайкальских бурят, эхирит-булагатов» (Ксенофонтов, 1992а: 16) ${ }^{1}$. К построениям Г. В. Ксенофонтова ныне написан достаточно качественный комментарий (Ушницкий, 2011).

Как отмечает В. В. Ушницкий, некоторые ученые (В. И. Рассадин, Б. З. Нанзатов, Д. Б. Цыбикдоржиев) пытаются отождествлять лингвистически этнонимы «курыкан» и «уранхай»; он же приводит сведения якутского фольклора о прародине саха в стране Ураанхай около Байкала, связывая их с курыканами (напр.: Цыбикдоржиев, 2003: 110). В этой связи представляется заманчивым констатировать этимологическую близость якутского эпонима “Урааныкаан” с урынкан. Однако урянхайцы в летописях поздних китайских династий упоминаются под именами улянха (волянха); и нет сведений об их связи с курыканами» (Ушницкий, 2010: 96; см. также: Нанзатов, 2016: 100).

Далее В. В. Ушницкий пишет: «По данным М. А. Кастрена, вероятна связь слова “урянхай” с кетским словом “уренгхит” ‘водяной (речной) человек’. Он считал, что термин “урянхит” сначала был самоназванием какого-то древнего, родственного кетам, “палеоазиатского” лесного племени Саяно-Алтайского района, занимавшегося охотой и рыболовством. Это племя распалось на несколько частей, в результате ассимиляции оно вошло в состав позднейших тюрков и монголов, в том числе якутов. Со временем было позабыто и их древнее самоназвание, которое сохранили степные народы как обозначение лесных жителей и которое имело пренебрежительный оттенок» (Ушницкий, 2010: 98). Как мы увидим далее, сохраняет свое значение цитированное Ксенофонтовым замечание Н. Ф. Катанова «Из данных языка и родовых имен можно вывести, что все урянхайцы - тюрки, представляющие смесь (уйгур, кыргыс, чоды, соян) и финнов или самоедов» (Ксенофонтов, 1992а: 92). Прав и сам В. В. Ушницкий, когда он говорит: «Но если вплоть до XIX в. в Южной и Восточной Сибири сохранялись этносы, представлявшие енисейские, самодийские, юкагирские и тунгусские языки, впоследствии окончательно отуреченные и монголизированные, то в XIII в. этническая картина региона могла быть еще более пестрой» (Ушницкий, 2013а: 69-70). Д. Д. Нимаев считает, что проблема этнической принадлежности курыкан значительно шире, чем поиски этимологии этнонима (Нимаев, 1988: 70).

В «Истории Бурятии» приводятся мнения Г. Н. Румянцева и Д. В. Цыбикдоржиева, развивающих гипотезу о происхождении этнонима урянхай от курыкан (История Бурятии, 2011: 262). Там же отмечено, что эта гипотеза была подвергнута критике Д. Д. Нимаевым (Нимаев, 2000: 66), который считает, что проблема этнической принадлежности курыкан значительно шире, чем поиски этимологии этнонима (Нимаев, 1988).

${ }^{1}$ Это предисловие, на которое при переиздании труда Г. В. Ксенофонтова в 1992 г. издатели не обратили внимания, требует определения авторства. Судя по всему, имя автора предисловия исчезло из издания в связи с репрессиями научных кадров сибиреведов в 1937 г. Как нам кажется, возможные его авторы - Н. Н. Козьмин (1872 - 21 августа 1938 г., арестован 23 августа 1937 г.) или, что менее вероятно, Б. Э. Петри (17 сентября 1884 г. - 25 ноября 1937 г.; арестован в мае 1937 г.). О них см.: Решетов, 2002; Романова 2003; Сирина, 2002. 
Нам необходимо разобраться, какой оним является первичным - название местности или название народа. В целом в рамках методов исследования ответ ясен: необходимо решить вопрос о появлении географического даже не названия, а понятия Урянхай, которое впоследствии дало названия какомуто этносу или скорее интерэтническому объединению, к чему склоняются многие исследователи. Эти данные частично использовались теми, кто брался исследовать вопрос о происхождении этнотопонима урянхай - этот термин позволит устраниться от повторов и повторения разнообразных утверждений относительно названий Урянхай и урянхайцы.

Авторы «Истории Тувы» отмечают «Кочевья тувинских племен в XVII и первой половине XVIII в. охватывали огромную территорию, включавшую в себя целый ряд горных систем и хребтов: Русский и Монгольский Алтай, Западный и Восточный Саян, Танну-Олу и др. На севере районы кочевий тувинцев достигали бассейна Верхней Оби и Минусинской котловины, на юге они простирались через Монгольский Алтай до верховьев Урунгу, Черного Иртыша, на востоке доходили до оз. Хубсугул, а на западе через Алтай достигали Иртыша» (История Тувы, 2001: 191).

В этом же издании подчеркивается: «В дореволюционной литературе и официальной документации тувинцев ошибочно именовали то “урянхайцами”, то “сойотами”, то “сойонами”. Сами тувинцы не называли себя урянхайцами, в их языке нет такого этнонима. Однако имеются основания полагать, что в прошлом, во всяком случае в XIII в., этноним “урянх", “урянкат” был известен в Южной Сибири и Монголии. Такое название тувинцам в XVIII - начале XX в. давали соседние народы. Скорее всего, это имя распространялось монголами, что подтвердил, в частности, и Г. Н. Потанин: “Название “урянхи” дают этому народу, - писал он, - монголы, а сами же себя зовут “туба” или “тува”” (там же: 308).

Н. В. Абаев считает, что «Если территория Древнего Урянхая, как мы полагаем, в узком смысле полностью совпадает с местоположением Эргунэ-Хун, то территория Эргенекон в широком смысле, по-видимому, захватывает и Тянь-Шань (тюркск. “Тэнгри-таг”), и Горный Алтай (“Алтай-Хонгорай”), и Хакасию (“Хоорай”), но Тува в любом случае остается одним из центров начальных этапов этногенеза “северных тюрков”, т. е. племен теле (“туры”), уйгуров, урянхайцев и др., которые позднее приняли участие и в этногенезе монголов Чингис-Хана, а потому в исторической памяти как тюрков, так и монголов, этнотопонимы Эргенекон и Эргунэ-Хун наложились друг на друга, но последний можно идентифицировать с Тоджинской котловиной, как с вполне реальным географическим местом» (Абаев, 2011: Электр. ресурс).

В огромной массе суждений историко-этнографического характера о границах области с названием Урянхай и расселении народа, в отношении к которому применялось название «урянхайцы», очень трудно найти подступы к новым и по-новому фундированным решениям существующих проблем.

Один из главных вопросов, от которого будет зависеть направление поисков и характер решения поставленных проблем - это языковая принадлежность и этимология топонимического именования Урянхай - мы пока на основе имеющихся в литературе материалов не можем, да и не сможем определить характер этого источникового топонима.

В. В. Ушницкий, один из современных активных исследователей проблемы, справедливо замечает: «Следовательно, границы Баргуджин-Тукума могли меняться в трудах разных авторов, поскольку этот термин в целом обозначал огромные лесостепные пространства Южной и Восточной Сибири» (Ушницкий, 2013a: 53). На подвижность границ в понимании Эргунэ-Куна указывают другие авторы (Зориктуев, 2011: 10-11; Скрынникова, 1993).

Важна и следующая цитата из труда Г. В. Ксенофонтова: «За Серошевским в деле разработки древней истории якутов можно признать ту заслугу, что он указал на двойное этническое наименование якутов, а именно, “ураангхай саха”, употребляющееся “в торжественных оборотах речи, в сказках, песнях и молитвах”. В связи с этим он обратил внимание ученых на тот общеизвестный факт, что дархаты, монголы и китайские чиновники тем же именем “уранхай” или “урянх” называют обитателей современной ТаннуТувинской республики или Урянхайского края» (Ксенофонтов, 1992а: 82).

В современных Интернет-форумах пользователи пишут: «Слово урангхай = от слова - Уран = умелый (умелый мастер (уран тарбах); умелый кузнец; умелый хлебопашец, умелый воин и т. п.)»1.

В. В. Ушницкий, рассматривая взгляды Г. В. Ксенофонтова, пишет: «По утверждению Г. В. Ксенофонтова, якутские уранхаи принадлежали к тунгусским племенам Маньчжурии, но еще в древности утратили свои этнические признаки и усвоили целиком турецкий язык и культуру. Он предполагал, что этноним “уранкай” вошел в язык саха в ходе ассимиляции тюркоязычными саха аборигенов края - тунгусов или

${ }^{1}$ forum.ykt.ru/viewtopic.jsp?id=4040166 
НОВЫЕ ИССЛЕДОВАНИЯ ТУВЫ

www.nit.tuva.asia

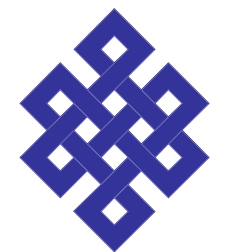

\section{THE NEW RESEARCH OF TUVA}

Novye issledovaniia Tuvy

эвенков. Сторонники тунгусского происхождения этнонима ураанхай, выводили происхождение этнонима “урянхай” от слов - орон “олень”, или урэнкэн “житель горной тайги” (Ушницкий, 2013a: 66).

Здесь уже начинаются странности. Приоритет Г. В. Ксенофонтова в связи наименований урянхай и орон не отмечен у Ю. Янхунена (Янхунен, 2018: 17-19) возможно, из-за того, что труд Г. В. Ксенофонтова не был указан в библиографии к работе Г. М. Василевич. Сама Г. М. Василевич писала: «Слово “уранкай” просится на сопоставление с тунгусским (эвенкийским, эвенским) урэ (ура, акающая огласовка), обозначающим “гора, покрытая лесом”, а суффикс -нкан-ь-нкай обозначает “житель”; таким образом, слово «уранкай» буквально переводится из эвенкийского как “житель горной тайги”. Так в сказаниях часто называют себя герои» (Василевич, 1966а: 340). Дело в том, что в слове урэ «гора» (эвен. урэ:кчэ:н) замена переднерядного гласного э на заднерядный $а$ невозможна.

B. В. Ушницкий, не уходя от проблемы связи топонима урянхай с древним фольклорным наименованием якутов, предполагает, что связь топонима урянхай с названием предков якутов вполне логична (Ушницкий 2013а: 68) и ссылается на мнения Г. В. Ксенофонтова (Ксенофонтов, 1992) и Г. Н. Румянцева (Румянцев, 1951: 80). По мнению В. В. Ушницкого, версию о тождестве этнонимов курыкан и уранхай из современных исследователей поддерживают бурятские ученые В. И. Рассадин, Д. В. Цыбикдоржиев и Б. З. Нанзатов, при этом В. И. Рассадин якобы ссылается на особенности тофаларского языка, в котором буква к отпадает и получается урынкан (Ушницкий, 2013a: 68). Последнее замечание - явное недоразумение: невозможно возводить название урянхай к тофаларскому языку1. Указание на миграции монголоязычных племен из Забайкалья в Маньчжурию (Батоева, 2017) относится к довольно поздним событиям: важнее то, что в Китае при династии Цин урянхаями называли всех лесных охотников (там же: 72).

Необходимо разобраться, какой оним является первичным - название местности или название народа. В целом в рамках методов исследования ответ ясен: необходимо решить вопрос о появлении географического даже не названия, а понятия Урянхай, которое впоследствии дало названия какому-то этносу или скорее интерэтническому объединению. Эти данные частично использовались теми, кто брался исследовать вопрос о происхождении этноопонима урянхай - этот термин позволит устраниться от повторов и повторения разнообразных утверждений относительно названий Урянхай и урянхайцы.

В. В. Ушницкий, обобщая итоги исследования урянхайской проблемы имел право сказать: «Однако, происхождение этнонима “ураанхай” является общеалтайской проблемой. Этноним “ураанхай” является самоназванием потомков, или названием родов и племен, вошедших в образование различных народов и племен. Так существование подобного этнонима зафиксировано среди калмыков, башкир, монголов, бурят, тувинцев, эвенков, маньчжур и алтайцев. Следовательно, такой этноним, имеется у народов всех трех языковых групп, входивших в алтайскую семью языков. Встречаются сообщения о существовании носителей подобного этнонима среди самодийских племен и кетов. Настоящей прародиной этнонима “уранхай” оказалась территория Маньчжурии. Так, известно о том, что корейцы называли маньчжур именем Оранкай. Китайские источники времен Минской династии и корейские источники часто сообщают о племени урянхайцев, помогавших 70 маньчжурам в борьбе против монголов. В них видят потомков урянхайских монголов, либо сильно монголизированное чжурчжэньское племя. По последним данным ляодунские урянхайцы являлись по своему происхождению ойратами, впоследствии они были ассимилированы маньчжурами. Урянхайцами в маньчжурских источниках названы также эвенки Маньчжурии - солоны» (Ушницкий, 2013а: 69-70). Здесь В. В. Ушницкий не совсем точен в характеристике источников: он только стремится акцентировать присутствие формы оранкай у корейцев. Г. М. Василевич (Василевич, 1966а: 65-75) действительно пыталась найти сходно звучащие этнонимы у соседей эвенков - кетов и самодийских народов, однако не смогла решить поставленную ею же задачу.

Н. В. Кюнер собрал сводку о возможных вариантах именования народа урянхай - улянха, улянхай, урянхай, урянхиты, уранкай, унянгай, волангай, оренгай, уренкат, волянхэтэ и т. д. (Кюнер, 1961: 367)².

Как отмечает Б. З. Нанзатов, по описанию регион, где проживали лесные урянхаты, находился высоко в таежных горах, где-то примерно в районе Присаянья-Прихубсугулья, или же в Окинском плато или Дархатской котловине (Нанзатов, 2008: 428). Это в общем не противоречит представлениям о былом местопроживании урянхайцев, как бы его ни называть.

\footnotetext{
${ }^{1}$ Похожая ошибка делается всеми, кто пытается сопоставлять этноним саха - самоназвание якутов с иранским этнонимом саки (в том числе Ушницкий, 2013a): в якутском языке древний исконно тюркский начальный согласный с- отпадает.

${ }^{2}$ В специальной работе Н. В. Кюнер пишет: «Последний вопрос, который надлежит рассмотреть, это вопрос о самом имени улянхай (урянхай). Впоследствии это имя получило широкое распространение среди народов (племен) алтайской группы языков и даже как бы утратило специальное этническое значение, превратившись в прозвище (кличку) или просто в нарицательное слово для обозначения обнищалого угнетённого народа. А так как именно в таком подчиненном
} 
Публикации В. В. Ушницкого в настоящее время наиболее насыщены материалом из источников по средневековой истории Центральной Азии. Обобщая исследованные источники, он пишет: «Следовательно, в Минский период урянхайцами назывался монголоязычный народ, образовавшийся после падения монгольских империй. В ходе междоусобных войн это кочевое образование было раздроблено, и вошло в состав других кочевых объединений как джунгары, чахары, халха и тувинцы. Часть оказалась в территории Западной Монголии и становится известным под именем алтайские урянхайцы. Таким образом, происхождение носителей имени урянхай связывается с одним, конкретным племенем хи (кумохи). Тот факт, что данное племя еще было известно под именем татаби, говорит о том, что улохоу или урянкхаты могли быть известными под именем южных шивэй, впоследствии ставших татарами Внутренней Монголии. Якутские предания свидетельствуют о возможности отдельного проникновения племени под именем ураанхай в территорию Якутии. О возможности участия степных урянкхатов через эвенкийское посредство в этногенезе саха можно только гадать, гипотетично, с ними можно связать происхождение Намского улуса. Якутские предания легендарную страну Ураанхай считают прародиной народа саха. Где искать эту прародину саха? Следует допустить, что именно Внутренняя Монголия, которую И. Страленберг первоначально указывал в качестве прародины саха, а Ю. А. Зуев считает прародиной кимеков и располагает там одну ветвь Канглы, отождествляя их с огузо-татарами, является древним местожительством саха. В монгольскую эпоху под этим именем были известны лесные, охотничьи племена Саян (сайн-урянхи), а также применительно к коренному этносу Эргуне-кун располагавшегося в горах Хингана и Приаргунья: улохоу - степные урянкхаты. Обитавшие в Восточном Забайкалье степные урянкхаты вошли в состав формирующегося монгольского этноса, возможно, часть стали хамниганамиконными эвенками (Ушницкий, 2013а: 82).

Надо иметь в виду, что урянхаев возводила к Хи (татаби) еще Л. Л. Викторова (Викторова, 1980: 5, 139, $156,160,165,181)$.

Г. В. Ксенофонтов совершенно корректно ставит вопрос об исходной форме названия урянхай, перспективной для анализа «VI. Теперь мы попытаемся разобраться в семасиологии имени “ураангхай”. Прежде всего, необходимо установить первоначальную форму этого имени, чтобы определить его возможное значение. Мы раньше ссылались на слова проф. Я Ф. Катанова, что коренные обитатели Танну-Тувинского края, говорящие по-турецки, у монголов и манчжур известны под именем “уриан-гхай”: “Монголы и манчжуры в правительственных бумагах зовут уриангхай” <..>. Ничего нельзя возразить против того положения, что якутская форма “ураангхай” в точности совпадает с монголо-манчжурским произношением. С другой стороны, наряду с именем ураангхай, мы констатировали в фольклоре верхоянских якутов и ранних вилюйчан имя “урааныкаан”. Откидывая долготы, которыми якуты вообще злоупотребляют, мы получаем “уранкан”. В фольклорном пережитке нужно видеть первичное произношение этого имени, свойственное его носителям, тогда как форма “ураангхай” могла родиться в процессе международного общения с монголо-манчжурскими племенами. Карагассы-оленеводы, бродящие на северной стороне Саянского хребта, и теперь называются нижнеудинскими бурятами “уранкан” (Ксенофонтов 1992b: 164-165).

\section{Лингвистическая проблематика исследования}

Любопытно, что народные этимологии имени урянхай появляются в литературе довольно рано, и Г. В. Ксенофонтов рассматривает и эти соображения, приводя сообщения Е. К. Яковлева, Г. Н. Потанина и Б. Б. Бамбаева, связывающих название урянхай с монгольским словом оронхой «оборванный, презренный» (Бамбаев, 1929; Ксенофонтов, 1992b: 165).

Здесь начинается то, что стало объектом внимания многих из пишущих о проблеме имени урянхай. Эти сравнения дали основания и самому Г. В. Ксенофонтову, и его последователям, для дальнейших

и обедненном положении оказались в позднейшее время обитатели урянхайского (верхне-енисейского края), то за ними и закрепилось такое наименование. Но раньше положение восточной группы урянхайцев, бывших хисцев, было иным, и в то время, несомненно, это имя имело определенное этническое содержание. Но когда оно впервые появляется в китайской литературе и в какой форме?

На этот вопрос удачный ответ дает своевременная догадка Л. Л. Викторовой, которая в своей диссертации "Раннее расселение монгольских племен" (Л., 1952 г.) предлагает рассматривать известное в китайской литературе VII-VIII вв. наименование владения Улохоу как первоначальную китайскую форму последующего наименования Улянха. Владение Улохоу, расположенное в верховьях Амура, как раз соответствует той местности, где в эпоху Чингис-хана и в предшествующее время было местонахождение племени (поколения) Улянха (Урянхат, Урянхит "Сокровенного сказания")» (Кюнер, 1958: 215). Отметим, что самостоятельный народ урянхаи на Байкале видел Б. Б. Дашибалов (Дашибалов, 2002: 52), однако оценка историографии вопроса об урянхайцах, данная в этой книге (там же: 50), на наш взгляд, завышена. 
НОВЫЕ ИССЛЕДОВАНИЯ ТУВЫ

www.nit.tuva.asia

рассуждений с одинаковыми объектами для сравнения и одинаковыми результатами. Он пишет: «Указанные попытки объяснить происхождение имени “уранхай” сами по себе не представляют большой ценности, ибо воспроизводят наивную народную этимологию, исходящую из фактов простого созвучия слов, но в этой этимологии монголов мы находим маленькое жемчужное зерно. Его мы видим в стародавней привычке монгольского народа сближать имя “уран-кай” со словом “орон-хой”. Это намекает на то, что “уранкан” первоначально произносилось “орон-кон”: орон-кон, (орон-кан), уран-кан, уран(ы)кан, урааныкаан.

Но, однако, что же представляет собой имя “орон-кон”? Оно есть нечто иное, как вполне законный и даже более основной вариант имени “оро(н)чон”, т. е. тунгусского народа, обитающего в Верхнем Амуре и в Северной Манчжурии. В древности орочонами назывались вообще все тунгусские племена Манчжурии» (Ксенофонтов, 1992b: 166) ${ }^{1}$.

В дальнейшем проблема происхождения имени урянхай у Г. В. Ксенофонтова увязывается с идеями об этногенезе тунгусов и соответствующим его времени представлениями о якутско-тунгусских связях: «VIII. Наша гипотеза о тождестве имен “ураангхай”, “оранхай”, “уран-кан”, “орончон”, “орочи” и “ороки” подтверждается рассмотренной ранее легендой о бородатом народе (айнах), сохранившейся у северных якутов и на Вилюе. Наличие в составе якутов-оленеводов и ранних вилюйчан тунгусских родов из Манчжурии (солонов и лучин) точно также свидетельствует о первичном тунгусизме коренных вилюйчан» (там же: 170$)$.

«Мы думаем, что именно в эту историческую эпоху (первый век н. э.) отуреченные тунгусские стрелки “урангхаи" с частью хуннских окраинных родов эвакуировались из Халхи в Приангарье, в Баргуджин-Тукум монгольских преданий, т. е. в обычное место убежища разбитых родов, где они и образовали народ, позже известный под названием юч-курыкан. Предположительно к этой же эпохе нужно приурочить и переселение на Вилюй местных отуреченных тунгусов с частью монгольских родов, которые в своей главной массе отходили в Урянхайский край и в сторону Енисея» (там же: 176).

Здесь, конечно, Г. В. Ксенофонтов выдает желаемое ему за действительное. Во-первых, приводимые им отождествления названий народов до сих пор не являются общепринятыми среди специалистов, не говоря уже об этимологических версиях. Во-вторых, «бородатыми» для жителей бассейна Вилюя по антропологическим различиям с ними самими, тунгусами или якутами, вполне могли быть чукчи (Бурыкин, 2013: 454-456), тем более, что и название Вилюй, похоже, чукотское по происхождению (Вылгилвээм «Березовая река», что идеально соответствует растительности по берегам реки) (там же: $180-182)$.

Ю. Янхунен, развивая идеи, представленные в специальной работе Г. М. Василевич и частично совпадающие с построениями Г. В. Ксенофонтова, уклоняется от обсуждения этимологии названия Урянхай (Janhunen, 2014). У Г. М. Василевич сказано: «Не затрагивая вопроса о первичном происхождении этого этнонима, мы можем отметить, что это общий термин, который относится к нескольким “лесным народам” и распространён от современных тюркоязычных популяций Саянского региона (тувинская группа) и Лены (якуты) до исторических и протоисторических групп в Хинганском регионе и далее к востоку Маньчжурии. Этот этноним зафиксирован в источниках, связанных с северными границами киданьского Ляо, средневековых монголов и Кореи позднего Средневековья. Группы с этим этнонимом также присутствуют в составе эвенков» (Василевич, 1966b: 56-93).

По мнению монгольского лингвиста А. Очира, этноним урянгхай может происходить от монгольского боевого клича «uria» (уриа) и слова «khan» (хан). Во-вторых, по его же мнению, название урянхай может быть словом из тунгусо-маньчжурских языков. В эвенкийском языке слово уранкај указывает на человека, а в языке негидальцев слова уранкај бэјэ означают «живой человек». Маньчжурское слово уранка представляет собой этническое название урянхайцев. Эвенки словом уранкај называли охотников, обитавших в горах и тайге Забайкалья и Амура (Очир, 2016: 177-178).

Тувинские топонимисты оставляют без внимания проблему названия урянхай (Чулуун, Донгак 2015: Электр. ресурс; Донгак, 2016, 2018: Электр. ресурс; Саая, Бадарч, Донгак, 2018; Ондар, 2007), и, похоже, поступают правильно, поскольку исторические названия мест не относятся к актуальной локальной топонимике. Кстати, далеко не все исследователи этнографии якутов придают значение форме ураангхай саха как чему-то значимому для этнической истории якутов (Маркова, 2009). Фольклористы, увлеченные поисками истории в якутском эпосе, не обращают внимание на то, что урянгхай-сахалар в некоторых текстах появляются с неба (Данилова, 2016). В новой монографии о тюрках Южной Сибири отмечается:

${ }^{1}$ В свете новых данных об исторической фонетике тунгусо-маньчжурских языков и якутского языка подобные преобразования слов невозможны и их выведение одного из другого неприемлемо. 
«Точная этимология термина урянхай (также ураанхай, урянхи) все еще обсуждается... В Монголии слово урянхай использовалось и все еще используется как очень распространенный общий термин, относящийся ко всему населению северо-западных регионов Монголии (в основном тюркоязычному, но также и монголоязычному). Поскольку до 1914 г. территория современной Тувы входила и в состав Монголии, термин урянхай относился ко всем тувинцам, а также к тоджинцам, сойотам и духа (цаатанам) (Тюркские народы восточной Сибири, 2008: 189 прим.).

С. И. Вайнштейн в своей книге «Мир кочевников Центра Азии» обещает читателю дать этимологию названия урянхай (Вайнштейн, 1991: 13), но вместо этого дает только отсылку на свою более раннюю работу, рассматривая важные, но хорошо знакомые источники (Вайнштейн, 1961: 30-31, прим. 76).

Мы не можем дать исчерпывающий обзор точек зрения по поводу происхождения имени урянхай, поскольку ряд мнений и характер сопоставлений у некоторых авторов находится в сфере лингвистической паранауки, в которой ономастика всегда давала и дает максимум примеров ${ }^{1}$. Поэтому здесь мы переходим к изложению результатов наших собственных разысканий.

\section{Самодийская этимология именования Урянхай и проблемы локализации объекта с этим именем}

Н. Г. Спафарий в 1675 г. записал в своем дорожном дневнике путешествия в Китай: «Вершины реки Иртыша текут из Монгольских гор, которые по-русски именуются Камень, и от того места разделяются вершины Иртыша на две протоки: и одну протоку называют монгольцы и калмыки Уренгой, а другую - Балаган. И от того места недалеко есть рубеж Китайского государства, и при вершине реки Иртыша кочует монгольской тайша Зурухта-кун» (Спафарий, 1882: 41-42; Спафарий, 1960: 33). По современным географическим представлениям Иртыш не образуется за счет слияния каких-либо двух рек. Однако слова «сквозь то озеро прошла река Иртыш» - это указание на озеро Зайсан, в которое впадает Черный Иртыш, а из него вытекает собственно Иртыш. Разделяются вершины Иртыша на две протоки: и одну протоку называют монгольцы и калмыки Уренгой, а другую - Балаган. Судя по всему, ни то, ни другое название не являются гидронимами и указывают на находящиеся поблизости объекты. Видимо, с этими реками связано замечание Г. В. Ксенофонтова: «У В. И. Вербицкого мы находим сообщение, что калмыкидвоеданцы, кочующие в южной части Алтая по реке Чуе, впадающей в Катунь, именуют себя «урянхай» (Ксенофонтов, 1992b: 128). В данном случае, очевидно, перед нами указание на какую-то группу ойратов, называемую по реке.

То, что в рассматриваемой нами литературе по проблеме имени урянхай осталась без внимания форма, приведенная Спафарием, в общем не удивительно. Удивительно другое, то, что сходные топонимы в общем бассейне Оби и Иртыша, где и ныне проживают финно-угорские и самодийские народы, топоним Уренгой и Новый Уренгой остаются и без объяснения, и даже без надежного определения языковой принадлежности - этих названий нет ни в одном из словарей топонимики России.

В ресурсах Интернета находятся следующие толкования названия Уренгой: УРЕНГОЙ - поселок городского типа, он дал название крупнейшему газоконденсатному месторождению; г. Н. Уренгой. Толкований ненецкого слова «нгури хой» несколько: 1) «обгорелый холм»; 2) «лысый холм»; 3) «холм, на котором растут лиственницы, пригодные для шестов чума»; 4) «холм, поросший желтой травой» ${ }^{2}$. В другом источнике говорится: «Существует несколько версий происхождения слова 'Уренгой’. В переводе с хантыйского языка слово ‘Уре’ означает ‘старица' (старое русло реки), в ненецком языке есть слово 'Нго', или остров, т. е. 'остров среди старого русла реки'. В некоторых источниках слово 'Уренгой’ переводится как 'лысый холм', 'холм, на котором растут лиственницы, пригодные для шестов чума', и 'холм, покрытый желтой травой’. Было время, когда считали, что слово 'Уренгой’ означает 'гиблое место'. Скорее всего, так называли Уренгой строители одного из лагерей ГУЛАГа, которые прокладывали железнодорожную магистраль Салехард - Игарка, строительство которой было свернуто после смерти Сталина» ${ }^{3}$ Этот же материал обобщен в выпускной квалификационной работе выпускницы вуза, где рассматривается ойконим Новый Уренгой (Пищулина, 2016).

В кратком топонимическом словаре Казахстана отмечены этноним урангаи «этническая группа тюрков», и топоним Урынкай, оставшийся без объяснения (Яворская, 2002).

\footnotetext{
${ }^{1}$ См.: Научный доклад ..., Электр. ресурс.

${ }^{2}$ http://www.bolshoyvopros.ru/questions/2737342-kakova-istorija-proishozhdenija-nazvanija-goroda-novyj-urengoĭ.html

${ }^{3}$ http://venividi.ru/node/4875
} 
НОВЫЕ ИССЛЕДОВАНИЯ ТУВЫ

www.nit.tuva.asia

Судя по всему, ни то, ни другое название, приведенное Н. Г. Спафарием, не являются гидронимами и указывают на находящиеся поблизости объекты: топоним Уренгой везде, где он встречается - самодийского происхождения, и довольно легко этимологизируется на самодийской основе ср. ненец. варё'-нгхой ‘гора с проталинами’ (ненец. варё, мн.ч. варё” ‘проталина', хой ‘гора, хребет. холм’).

Самое интересное, что в тувинской топонимии есть сходное образование, для которого не была определена этимология - это гидроним Уран-сай, объясняемый как уран «искусный, умелый» + сай «галька, мель» (в казахском «балка, лощина, сухое русло небольшой реки») (Ондар, 2007: 419). Здесь, конечно, значение названия «балка, лощина с проталинами».

Найденная этимология названия географического пространства Урянхай в виде ненецкого варёнг-хой ‘гора с проталинами' не встречает ни одного противоречия: название в этой интерпретации как нельзя лучше соответствует горному рельефу местности в Туве и вокруг нее, и характеризует какие-то ее участки с точки зрения полезности для местных жителей-скотоводов, что актуально для хозяйства территории и поныне. Видимо, не случайно источники фиксируют название Урянхай с начальным согласным в-, который до полной адаптации или до полной ассимиляции самодийских народов на этой территории мог еще сохраняться в вариантах названия. Поиски самодийского и енисейского субстрата в Урянхайском крае в течение долгого времени привлекали внимание лингвистов и подпитывались большим количеством тюркизмов в сохранившихся словниках по языкам южносамодийских и енисейских народов, стимулировавшими лингвистов на разыскание аналогичного влияния этих языков на тюркские языки, в первую очередь на тувинский, тофаларский, языки тувинцев-тоджинцев и сойотов. Однако в самом раннем сойотском словаре 1819 г. мы нашли только одно слово самодийского происхождения кат - «ветер» (ср. тув. хат «ветер») (Бурыкин, Насилов, 2014).

Становится ясным, что поиски нетюркских и немонгольских элементов в языках народов Центральной Азии представляют гораздо более сложную задачу, чем это представлялось ранее. Но и здесь есть сюрпризы. К нашей теме об именовании якутов ураангхай-сахалар имеет прямое отношение термин-название якутского эпоса олонхо. Это якутское слово не имеет ни тюркской, ни монгольской этимологии, если говорить о приемлемых и достоверных соответствиях слов. Но нельзя не отметить, что оно чрезвычайно похоже на ненецкое слово лаханако «сказка, рассказ, разговор», образованное от глагола лаханась «говорить», ср еще лаханакось, лаханорць «разговаривать, беседовать» (Хомич, 1954: 25).

Объяснение топографического имени Урянхай, предложенное нами, по существу уравняло именование Урянхай даже не с названиями мест, а с географическими апеллятивами - любая гора с проталинами, привлекающая скотоводов, называется по-ненецки варёнгхой. Понятно, что не случайно историческая Тува как место формирования и расселения тувинского этноса получила название Урянхайский край. Название территории распространялось на жителей этого края, кем бы они ни были по этнической принадлежности - тюрками или монголами. Современный этноним урянхайцы связывается с некоторыми группами монголоязычных субэтносов (Агеева, 2000: 320-322).

Г. В. Ксенофонтов, занимаясь поисками связей якутов, в фольклоре которых присутствует именование ураангхай-саха, во многом ориентировался на построения лингвистов - его предшественников и современников, занимавшихся поисками классификации тюркских языков. В это время - в конце XIX первой трети XX в. - место якутского языка в классификации тюркских языков не было окончательно определено, и многие связи, наблюдаемые между якутским и другими тюркскими языками, выглядели иллюзорными и в наше время рассуждения ученого в этой сфере представляют чисто исторический интерес (см. историю вопроса в лингвистическом плане (Левин, 2010: Электр. ресурс). В настоящее время якутский язык в классификациях тюркских языков занимает особую позицию (Сравнительно-историческая грамматика, 2002: 10; Широбокова, 2005: 5-51), более того, сам язык обладает свойством изменяться по значимым классификационным параметрам группы языков (Широбокова, 2015: 249 ).

\section{Заключение}

Проблема фольклорного этнонима ураангхай саха, во всяком случае, до тех пор, пока не будет показано, что этот этноним есть чисто фольклорное явление, распространившееся вместе с самими эпическими произведениями, может связываться с миграциями тюркоязычных этнических групп к северу от исторического Баргуджин-Тохума в Прибайкалье и в бассейн Лены. Собственно говоря, современные лингвисты-якутоведы и находят ему место в территориальных наименованиях разных групп якутов, имеющих различное происхождение за счет поглощения каких-то соседей, чаще всего тунгусоязычных 
(Ефремов, 2001: Электр. ресурс). Однако причины этих миграций следует искать не во взаимоотношениях этносов и этнических конфликтах с сильными соседями, а совсем в другом - в колебаниях климата Сибири и Центральной Азии, которые стали предметом фундаментальных исследований относительно недавно (см.: Борисенков, Пасецкий 1988; Леви и др., 2003; Задонина, Леви, 2009). Мы сейчас можем с уверенностью связывать с колебаниями климата по крайней мере два знаменательных факта в истории Восточной Сибири - это переход курыкан (предков якутов) из Прибайкалья в бассейн Лены примерно в VII в. и почти синхронная с ним параллельная по направлению миграция предков северных тунгусов на левый берег Амура, и потепление XIII в., вызвавшее вторую миграционную волну в бассейн Лены, в которой участвовали монголоязычные этнические группы (Бурыкин, Шарина, 2016). Вполне возможно, что ключом к проблеме распространения именования Ураангкай-саха в якутском фольклоре является не этническая история народа саха, а фольклорные взаимосвязи тюркских и монгольских народов, где особое внимание привлекают параллели из тувинского эпоса и богатырских сказок к мотивам якутского эпоса и эпических произведений тунгусо-маньчжурских народов.

\section{СПИСОК ЛИТЕРАТУРЫ}

Абаев, Н. В. (2011) О прародине всех тюрков и монголов: «Эргенекон», «Эргунэ-хун» или Танну-Урянхай? [Электронный ресурс] // Новые исследования Тувы. № 1. URL: https://nit.tuva.asia/nit/article/view/448 (дата обращения: 01.03.2019).

Агеева, Р. А. (2000) Какого мы роду-племени? Народы России: имена и судьбы. Словарь-справочник. М. : Academia. $424 \mathrm{c}$.

Бамбаев, Б. Б. (1929) К вопросу о происхождении бурят-монгольского народа. Верхнеудинск : Тип. БГИ. 21 с.

Батоева, Д. Б. (2017) Миграции монголоязычных племен Забайкалья на территорию Маньчжурии // Oriental Studies. № 6. C. 71-78.

Борисенков, Е. П., Пасецкий, В. М. (1988) Тысячелетняя летопись необычайных явлений природы. М. : Мысль. 524 c.

Бурыкин, А. А. (2013) Имена собственные как исторический источник. По материалам русских документов об открытии Сибири и Дальнего Востока XVII-XIX вв. СПб. : Петербургское востоковедение. 539 с.

Бурыкин, А. А., Насилов, Д. М. (2014) Записи сойотских слов, опубликованные в «Сибирском вестнике» Г. И. Спасского (1819 г.) // Материалы Международной научной конференции «Актуальные проблемы современного монголоведения и алтаистики», посвященной 75-летию со дня рождения и 55-летию научно-педагогической деятельности профессора В. И. Рассадина (г. Элиста, 10-13 ноября 2014 г.). Элиста : Изд-во КалмГУ. 523 с. С. 19-25.

Бурыкин, А. А., Шарина, С. И. (2016) Средневековые миграции народов Средней и Восточной Сибири: поиски причин и анализ последствий // Великие евразийские миграции. Материалы Международной научной конференции. 11-14 октября 2016 г. / [редакционная коллегия: В. И. Колесник (отв. ред.) и др.]. Элиста: Изд-во КалмГУ. 457 с. С. $133-139$.

Вайнштейн, С. И. (1961) Тувинцы-тоджинцы. Историко-этнографические очерки. М. : Изд-во Восточная литература. 218 с.

Вайнштейн, С. И. (1991) Мир кочевников Центра Азии. М. : Наука. 296 с.

Василевич, Г. М. (1966а) Исторический фольклор эвенков. Сказания и предания. М. ; Л. : Наука. 400 с.

Василевич, Г. М. (1966b) Уранкаи-эвенки // Доклады по этнографии ВГО. Сборник. Вып. 4 / отв. ред. С. И. Руденко. Л. : Изд. ВГО. 114 с. С. $56-93$.

Викторова, Л. Л. (1980) Монголы. Происхождение народа и истоки культуры. М. : ГРВЛ. 224 с.

Данилова, А. Н. (2016) Чудесное рождение богатырки как архаический мотив в якутских олонхо о женщинах-богатырках // Филологические науки. Вопросы теории и практики. Тамбов: Грамота. № 11 (65): в 3-х ч. Ч. 3. С. 30-33.

Дашибалов, Б. Б. (2002) Очерки по древней и средневековой истории монголов и бурят. Улан-Удэ : ОАО «Республиканская типография». 80 с.

Донгак, А. С. (2015) Сюжетно-тематические циклы топонимических преданий Юго-Восточной Тувы // Всеобщая история. № 3. С. 17-26.

Донгак, А. С. (2016) Топонимические предания и легенды Юго-Восточной Тувы: локальное своеобразие в русле межкультурных контактов // Сибирский форум фольклористов: тезисы докладов / отв. ред. Е. Н. Кузьмина. Новосибирск : ООО «Академиздат». 188 с. С. 54-56.

Донгак, А. С. (2018) Топонимические предания и легенды Юго-Восточной Тувы [Электронный ресурс] // Новые исследования Тувы. № 3. URL: https://nit.tuva.asia/nit/article/view/793 (дата обращения: 01.03.2019). DOI: 10.25178/ nit.2018.3.9 
Дьячкова, А. Н. (1999) Г. В. Ксенофонтов: Ученый и общественно-политический деятель : дисс. ... канд. ист. наук. Якутск. 194 с.

Дьячкова, А. Н. (2000) Г. В. Ксенофонтов: ученый и общественный деятель. Якутск : Изд-во Якутского гос. ун-та. 203 c.

Ефремов, Н. Н. (2001) Старинное название якутов было ураангкай... [Электронный ресурс] // Илин. № 3-4. URL: http://ilin-yakutsk.narod.ru/2001-34/12.htm (дата обращения: 01.03.2019). DOI: 10.25178/nit.2018.3.9

Задонина, Н. В., Леви, К. Г. (2009) Хронология природных и социальных феноменов в истории мировой цивилизации. Иркутск : Изд-во Иркут. гос. ун-та. 863 с.

Зориктуев, Б. Р. (2011) Актуальные проблемы истории монголов и бурят. М. : Восточная литература. 278 с.

История Бурятии (2011): в 3 т. / гл. ред. и рук. проекта Б. В. Базаров. Улан-Удэ : Изд-во БНЦ СО РАН. Т. 1. Древность и средневековье. 328 с.

История Тувы (2001). 2-е изд., перераб. и доп. / под общей ред. С. И. Вайнштейна, М. Х. Маннай-оола. Новосибирск : наука. Т. I. 367 с.

Ксенофонтов, Г. В. (1992а) Ураангхай-сахалар : Очерки по древ. истории якутов. Якутск : Нац. изд-во Респ. Саха (Якутия). 20 см. Т. 1. Кн. 1.416 с.

Ксенофонтов, Г. В. (1992b) Ураангхай-сахалар : Очерки по древ. истории якутов. Якутск : Нац. изд-во Респ. Саха (Якутия). 20 см. Т. 1. Кн. 2. 416 с.

Кузьмин, С. Л. (2018) Урянхайский вопрос и монголо-тувинские отношения в начале XX века // Oriental Studies. № 3. C. 2-14.

Кюнер, Н. В. (1958) Восточные урянхайцы по китайским источникам // УЗ ТНИИЯЛИ. Вып. VI. / отв. ред. Н. А. Сердобов. Кызыл. 306 с. С. 202-216.

Кюнер, Н. В. (1961) Китайские известия о народах Южной Сибири, Центральной Азии и Дальнего Востока. М. : Изд-во Восточная литература. 392 с.

Леви, К. Г., Задонина, Н. В., Бердникова, Н. Е., Воронин, В. И., Глызин, А. В., Язев, С. А., Баасанджав, Б., Нинжбадгар, С., Балжинням, Б., Буддо, В. Ю. (2003) Современная геодинамика и гелиогеодинамика. Книга II. 500-летняя История аномальных явлений в природе и социуме Сибири и Монголии. Иркутск : Издательство Иркутского государственного технического университета. 383 с.

Левин, Г. Г. (2010) О происхождении якутского языка в этнографических и лингвистических трудах исследователей XVII-XIX вв. [Электронный ресурс] // Ученые записки. № 4 (16). URL: www.scientific-notes.ru/pdf/017-18.pdf (дата обращения: 01.03.2019).

Маркова, М. Ф. (2009) Отечественная историография этнографии якутов : автореф. дисс. ... канд. ист. наук. УланУдэ. 26 с.

Нанзатов, Б. 3. (2008) Расселение и племенной состав номадов Центральной Азии в пред-чингисовское и чингисовское время (по данным летописей Рашид-ад-Дина) // Монгольская империя и кочевой мир : сборник статей / редкол.: Б. В. Базаров, Н. Н. Крадин, Т. Д. Скрынникова. Улан-Удэ : Изд-во Бурят. науч. центра СО РАН. Кн. 3. С. $377-443$.

Нанзатов, Б. 3. (2016) К вопросу о ранней этнической истории баргу-бурятской общности // Oriental Studies. № 1. C. 99-106.

Научный доклад «”Паранаука” в современной отечественной лингвистике». Докладчик член-корреспондент РАН Березович Елена Львовна (УрФУ). г. Екатеринбург [Электронный ресурс] // Российская академия наук. Уральское отделение. URL: http://uran.ru/node/5153 (дата обращения: 01.03.2019).

Нимаев, Д. Д. (1988) Проблемы этногенеза бурят. Новосибирск : Наука, Сибирское отделение. 167 с.

Нимаев, Д. Д. (2000) Буряты: этногенез и этническая история. Улан-Удэ : ВСГАКИ. 190 с. 552 с.

Ондар, Б. К. (2007) Топонимический слвоарь Тувы. 2-е изд. перераб. Кызыл : Тувинское книжное издательство.

Очир, А. (2016) Монгольские этнонимы: вопросы происхождения и этнического состава монгольских народов / Э. П. Бакаева, К. В. Орлова. Элиста : КИГИ РАН. 286 с. С. 175-178.

Пищулина, В. Е. (2016) Происхождение, структура и семантика топонимов ЯНАО : выпускная квалификационная работа. Тобольск : Тобольский пед. инст-т им. Д. И. Менделеева. 73 с.

Решетов, А. М. (2002) Николай Николаевич Козьмин: основные направления научной деятельности // Репрессированные этнографы / под ред. Д. Д. Тумаркина. М. : Изд-во «Восточная литература» РАН. 343 с. С. 81-100.

Романова, Е. Н. (2003) Г. В. Ксенофонтов: миф о странствующем герое // Репрессированные этнографы. Вып. 2 / сост. и отв. ред. Д.Д. Тумаркин. М. : Восточная литература. 495 с. С. 78-104.

Румянцев, Г. Н. (1951) Родоплеменной состав верхоленских бурят // Записки Бурят-монгольского НИИ культуры. Вып. ХІІ. Улан-Удэ Бурмонгиз. 160 с. С. 78-108. 
Саая, О. М., Бадарч, Б., Донгак, А. С. (2018) Этнокультурные традиции урянхайцев Монголии (на материале полевых исследований) // Азия и Африка сегодня. № 10 (735). С. 68-74.

Сирина, А. А. (2002) Забытые страницы сибирской этнографии: Б. Э. Петри // Репрессированные этнографы / под ред. Д. Д. Тумаркина. М. : Изд-во «Восточная литература» РАН. 343 с. С. 57-80.

Скрынникова, Т. Д. (1993) Этнотопоним Баргуджин-Токум // История и культура народов Центральной Азии / отв. ред. Ш. В. Чимитдоржиев. Улан-Удэ : Изд-во БНЦ СО РАН. 138 с. С. 41-49.

Спафарий, Н. Г. (1882) Путешествие через Сибирь от Тобольска до Нерчинска и границ Китая русского посланника Николая Спафария в 1675 году. Дорожный дневник Спафария / с введ. и примеч. Ю. В. Арсеньева. СПб. : Тип. В. Киршбаума. 214 с.

Спафарий, Н. Г. (1960) Сибирь и Китай. Кишинев : Картя Молдовеняскэ. 514 с.

Сравнительно-историческая грамматика тюркских языков. Региональные реконструкции (2002) / отв. ред. Э. Р. Тенишев. М. : Наука. 767 с.

Тюркские народы Восточной Сибири (2008) / отв. ред. Д. А. Функ, Н. А. Алексеев. М. : Наука. 422 с.

Ушницкий, В. В. (2010) Проблема происхождения этнонима урянхай // Гуманитарные науки в Сибири. № 4. C. 96-99.

Ушницкий, В. В. (2011) Историография этногенеза Саха: обзор научных гипотез и версий // Вестник НгУ Серия филология, философия. Т. 10, вып. 5. Археология и этнография. С. 73-81.

Ушницкий, В. В. (2013) Население Байкальского региона в эпоху средневековья (к проблеме этногенеза саха). Якутск : Изд-во ИГИиПМНС СО РАН. 173 с.

Хомич, Л. В. (1954) Ненецко-русский словарь. Л. : Учпедгиз. 122 с.

Цыбикдоржиев, Д. В. (1996) К вопросу о происхождении этнонима курыкан // Гуманитарные исследования молодых ученых Бурятии : сборник статей / Янгутов Л. Е. (отв. ред.) и др. Улан-Удэ : БИОН. 199 с. С. $143-148$.

Чулуун, С., Донгак, А. С. (2015) Этнокультурные контакты народов Саяно-Алтая и Западной Монголии [Электронный ресурс] // Новые исследования Тувы. № 1. URL: https://nit.tuva.asia/nit/article/view/54 (дата обращения: 01.02.2019). 269 c.

Широбокова, Н. Н. (2005) Отношение якутского языка к тюркским языкам Южной Сибири. Новосибирск : Наука.

Широбокова, Н. Н. (2015) О смене классификационного типа (на материале тюркских языков Сибири) // Сибирский филологический журнал. № 4. С. 242-250.

Яворская, В. Н. (2002) Краткий топонимический словарь казахских географических названий и русских географических терминов. Петропавловск : Изд-во Североказахстанского университета. 27 с.

Янхунен, Ю. (2018) Об этнонимах ороки и урянхай // Россия и АТР. № 4. С. 11-24.

Janhunen, J. (2014) On the ethnonyms Orok and Uriankhai // Studia Etymologica Cracoviensia. Vol. 19. P. 71-81.

Дата поступления: 12.03.2019 2.

\section{REFERENCES}

Abaev, N. V. (2011) O prarodine vsekh tiurkov i mongolov: «Ergenekon», «Ergune-khun» ili Tannu-Uriankhai? [On the homeland of all Turks and Mongols: "Ergenekon", "Ergune-khun" or Tannu-Uriankhai?]. The New Research of Tuva, no. 1 [online] Available at: https://nit.tuva.asia/nit/article/view/448 (access date: 01.03.2019).

Ageeva, R. A. (2000) Kakogo my rodu-plemeni? Narody Rossii: imena i sud'by. Slovar'-spravochnik [Who are our ancestors? Peoples of Russia: names and fates. A consise dictionary and reference book]. Moscow, Academia Publ. 424 p. (In Russ.).

Bambaev, B. B. (1929) K voprosu o proiskhozhdenii buriat-mongol'skogo naroda [On the issue of origin of Buryat-Mongols]. Verkhneudinsk, BGI Publ. 28 p. (In Russ.).

Batoeva, D. B. (2017) Migratsii mongoloiazychnykh plemen Zabaikal'ia na territoriiu Man'chzhurii [Migrations of Mongolspeaking tribes from Transbaikalia to the territory of Manchuria]. Oriental Studies, no. 6, pp. 71-78. (In Russ.).

Borisenkov, E. P. and Pasetskii, V. M. (1988) Tysiacheletniaia letopis' neobychainykh iavlenii prirody [A thousand-year chronicle of extraordinary natural phenomena]. Moscow, Mysl'. 524 p. (In Russ.).

Burykin, A. A. (2013) Imena sobstvennye kak istoricheskii istochnik. Po materialam russkikh dokumentov ob otkrytii Sibiri $i$ Dal'nego Vostoka XVII-XIX vv. [Proper names as a historical source: from the Russian documents on the discovery of Siberia and the Far East, 17th to 19th centuries]. St. Petersburg, Peterburgskoe vostokovedenie. 536 p. (In Russ.).

Burykin, A. A. and Nasilov, D. M. (2014) Zapisi soiotskikh slov, opublikovannye v «Sibirskom vestnike» G. I. Spasskogo (1819 g.) [Recordings of Soiot words, published in the "Sibirsky vestnik" by G. I. Spassky (1819)]. In: Materialy Mezhdunarodnoi nauchnoi konferentsii «Aktual'nye problemy sovremennogo mongolovedeniia $i$ altaistiki», posviashchennoi 75-letiiu so dnia rozhdeniia i 55-letiiu nauchno-pedagogicheskoi deiatel'nosti professora V. I. Rassadina (g. Elista, 10-13 noiabria 2014 g.) 
[Proceedings of the international conference "Urgent issues of contemporary Mongolian and Altaic studies", dedicated to the 75th anniversary of the birth and the 55th anniversary of the research and educational work of Prof. V. I. Rassadin]. Elista, Kalmyk University Publishers. 523 p. Pp. 19-25. (In Russ.).

Burykin, A. A. and Sharina, S. I. (2016) Srednevekovye migratsii narodov Srednei i Vostochnoi Sibiri: poiski prichin i analiz posledstvii [Medieval migrations of the peoples of Middle and Eastern Siberia: Search for causes and analysis of consequences]. In: Velikie evraziiskie migratsii [Great Eurasian migrations]. Proceedings of an international conference October 11-14, 2016. V. I. Kolesnik (ed.). Elista, Kalmyk University Publishers. 457 p. Pp. 133-139. (In Russ.).

Vainshtein, S. I. (1961) Tuvintsy-todzhintsy. Istoriko-etnograficheskie ocherki [Tozhu tuvans: historical and ethnographic essays]. Moscow, Nauka. 218 p. (In Russ.).

Vainshtein, S. I. (1991) Mir kochevnikov Tsentra Azii [The world of nomads of Central Asia]. Moscow, Nauka. 296 p. (In Russ.).

Vasilevich, G. M. (1966a) Istoricheskii fol'klor evenkov. Skazaniia i predaniia [Historical folklore of the Evenki: Stories and Legends]. Moscow, Leningrad, Nauka. 400 p. (In Russ.).

Vasilevich, G. M. (1966b) Uriankhai-evenki [The Uriankhaians-Evenki]. In: Doklady po etnografii VGO. Vol. 4 / ed. by S. I. Rudenko. Leningrad, VGO Publ. 114 p. Pp. 56-93. (In Russ.).

Viktorova, L. L. (1980) Mongoly. Proiskhozhdenie naroda i istoki kul'tury [The Mongols. The origin of people and the sources of their culture]. Moscow, Nauka Oriental literature publishers. 224 p. (In Russ.).

Danilova, A. N. (2016) Chudesnoe rozhdenie bogatyrki kak arkhaicheskii motiv v iakutskikh olonkho o zhenshchinakhbogatyrkakh [The miraculous birth of a bogatyr woman as an archaic motif in Yakut Olonkho on female bogatyrs]. Filologicheskie nauki. Voprosy teorii i praktiki, no. 11 (65): in 3 parts. Part 3. Pp. 30-33. (In Russ.).

Dashibalov, B. B. (2002) Ocherki po drevnei i srednevekovoi istorii mongolov i buriat [Essays on the ancient and medieval history of the Mongols and Buryats]. Ulan-Ude, Republican Printing House OJSC. 80 p. (In Russ.).

Dongak, A. S. (2015) Siuzhetno-tematicheskie tsikly toponimicheskikh predanii Iugo-Vostochnoi Tuvy [Subject-thematic cycles of toponymic tales of South-Eastern Tuva]. Vseobshchaia istoriia, no. 3, pp 17-26. (In Russ.).

Dongak, A. S. (2016) Toponimicheskie predaniia i legendy Iugo-Vostochnoi Tuvy: lokal'noe svoeobrazie v rusle mezhkul'turnykh kontaktov [Toponymic oral tales and legends of South-Eastern Tuva: local originality in the course of intercultural contacts]. In: Sibirskii forum fol'kloristov [Siberian Forum of Folklorists]: Abstracts / ed. by E. N. Kuz'min. Novosibirsk, OOO «Akademizdat». 188 p. Pp. 54-56. (In Russ.).

Dongak, A. S. (2018) Toponimicheskie predaniia i legendy Iugo-Vostochnoi Tuvy [Toponymic oral tales and legends of South-Eastern Tuva]. The New Research of Tuva, no. 3 [online] Available at: https://nit.tuva.asia/nit/article/view/793 (access date: 01.03.2019). DOI: 10.25178/nit.2018.3.9 (In Russ.).

D'iachkova, A. N. (1999) G. V. Ksenofontov: Uchenyi i obshchestvenno-politicheskii deiatel' [G. V. Ksenofontov, scholar and socio-political activist]: Diss.... Candidate of History. Iakutsk. 194 p. (In Russ.).

D'iachkova, A. N. (2000) G. V. Ksenofontov: uchenyi i obshchestvennyi deiatel' [G. V. Ksenofontov, scholar and public figure]. Yakutsk, Yakutsk State University Publ. 203 p. (In Russ.).

Efremov, N. N. (2001) Starinnoe nazvanie iakutov bylo uraangkai... [Yakuts' ancient name was the Uriankhai...]. Ilin, no. 3-4 [online] Available at: http://ilin-yakutsk.narod.ru/2001-34/12.htm (access date: 01.03.2019). DOI: 10.25178/ nit.2018.3.9 (In Russ.).

Zadonina, N. V. and Levi, K. G. (2009) Khronologiia prirodnykh i sotsial'nykh fenomenov $v$ istorii mirovoi tsivilizatsii [A chronology of natural and social phenomena in the history of global civilisation]. Irkutsk, Irkutsk State University Publ. 863 p. (In Russ.).

Zoriktuev, B. R. (2011) Aktual'nye problemy istorii mongolov i buriat [Urgent issues in the history of Mongols and Buryats]. Moscow, Vost. lit. Publ. 278 p. (In Russ.).

Istoriia Buriatii [A History of Buryatia] (2011): in 3 vols. / ed. by B. V. Bazarov. Ulan-Ude, BNTs SO RAN Publ. Vol. 1. Drevnost' i srednevekov'e [Antiquity and the Middle ages]. 328 p. (In Russ.).

Istoriia Tuvy [The History of Tuva] (2001). 2nd ed. / ed. by S. I. Vainshtein and M. Kh. Mannai-ool. Novosibirsk, Nauka. Vol. I. 367 p. (In Russ.).

Ksenofontov, G. V. (1992a) Uraangkhai-sakhalar : Ocherki po drevnei istorii iakutov [Urianghai-sakhalar: Essays in ancient history of Yakuts]. Iakutsk, National publishing house of the Republic of Sakha (Yakutia). Vol. 1. Book 1. 416 p. (In Russ.).

Ksenofontov, G. V. (1992b) Uraangkhai-sakhalar: Ocherki po drevnei istorii iakutov [Urianghai-sakhalar: Essays in ancient history of Yakuts]. Iakutsk, National publishing house of the Republic of Sakha (Yakutia). Vol. 1. Book 2. 416 p. (In Russ.).

Kuz'min, S. L. (2018) Uriankhaiskii vopros i mongolo-tuvinskie otnosheniia v nachale KhKh veka [The Uriankhai issue and Mongol-Tuvan relations at the beginning of the 20th century]. Oriental Studies, no. 3, pp. 2-14. (In Russ.).

Kiuner, H. V. (1958) Vostochnye uriankhaitsy po kitaiskim istochnikam [Eastern Uriankhai in Chinese sources]. In: UZ TNIIIaLI. Vol. VI. / ed. by N. A. Serdobov. Kyzyl, s. n. 306 p. Pp. 202-216. (In Russ.).

Kiuner, N. V. (1961) Kitaiskie izvestiia o narodakh Iuzhnoi Sibiri, Tsentral'noi Azii i Dal'nego Vostoka [Chinese news about the peoples of South Siberia, Central Asia and the Far East]. Moscow, Vost. Lit Publ. 392 p. (In Russ.). 
Levi, K. G., Zadonina, N. V., Berdnikova, N. E., Voronin, V. I., Glyzin, A. V., Iazev, S. A., Baasandzhav, B., Ninzhbadgar, S., Balzhinniam, B. and Buddo, V. Iu. (2003) Sovremennaia geodinamika i geliogeodinamika. Kniga II. 500-letniaia Istoriia anomal'nykh iavlenii v prirode i sotsiume Sibiri i Mongolii [Modern geodynamics and heliogeodynamics. Book II. A 500-year history of anomalous phenomena in the nature and society of Siberia and Mongolia]. Irkutsk, Irkutsk State technical University Publishers. 383 p. (In Russ.).

Levin, G. G. (2010) O proiskhozhdenii iakutskogo iazyka v etnograficheskikh i lingvisticheskikh trudakh issledovatelei XVII-XIX vv. [On the origin of the Yakut language in ethnographic and linguistic works of 17th-19th century researchers]. Uchenye zapiski, no. 4 (16) [online] Available at: www.scientific-notes.ru/pdf/017-18.pdf (access date: 01.03.2019). (In Russ.).

Markova, M. F. (2009) Otechestvennaia istoriografiia etnografii iakutov [Russian historians on the ethnography of Yakuts]: Thesis of Diss.... Candidate of History. Ulan-Ude. 26 p. (In Russ.).

Nanzatov, B. Z. (2008) Rasselenie i plemennoi sostav nomadov Tsentral'noi Azii v pred-chingisovskoe i chingisovskoe vremia (po dannym letopisei Rashid-ad-Dina) [Spread and tribe nomenclature of Central Asian nomads in pre-Chingisian and Chingisian times (according to the chronicles of Rashid-ad-Din)]. In: Mongol'skaia imperiia i kochevoi mir [The Mongol Empire and nomadic world]: a collection of articles / edited by B. V. Bazarov, N. N. Kradin and T. D. Skrynnikova. Ulan-Ude, BNTs SO RAN Publ. Book 3. Pp. 377-443. (In Russ.).

Nanzatov, B. Z. (2016) K voprosu o rannei etnicheskoi istorii bargu-buriatskoi obshchnosti [On the issue of early ethnic history of the Bargu-Buryat community]. Oriental Studies, no. 1, pp. 99-106. (In Russ.).

Nauchnyi doklad «"Paranauka” v sovremennoi otechestvennoi lingvistike». Dokladchik chlen-korrespondent RAN Berezovich Elena L'vovna (UrFU). g. Ekaterinburg ["Para-science" in modern Russian linguistics. A report by Corresponding Member of RAS Elena Lvovna Berezovich (UrFU). Ekaterinburg]. Rossiiskaia akademiia nauk. Ural'skoe otdelenie [online] Available at: http://uran.ru/node/5153 (access date: 01.03.2019). (In Russ.).

Nimaev, D. D. (1988) Problemy etnogeneza buriat [The problems of the ethnogenesis of Buryats]. Novosibirsk, Nauka, Siberian Branch Publishers. 167 p. (In Russ.).

Nimaev, D. D. (2000) Buriaty: etnogenez i etnicheskaia istoriia [The Buryats: ethnogenesis and ethnic history]. Ulan-Ude, VSGAKI Publ. 190 p. (In Russ.).

Ondar, B. K. (2007) Toponimicheskii slovar' Tuvy [A toponymical dictionary of Tuva]. $2^{\text {nd }}$ ed. Kyzyl, Tuvan publishing house. 552 p. (In Russ.).

Ochir, A. (2016) Mongol'skie etnonimy: voprosy proiskhozhdeniia i etnicheskogo sostava mongol'skikh narodov [Mongol ethnonyms: the origin and the ethnic composition of the Mongolian peoples]. Elista, KIGI RAN. 286 p. (In Russ.).

Pishchulina, V. E. (2016) Proiskhozhdenie, struktura i semantika toponimov IaNAO [Origin, structure and semantics of the toponyms of Yamal-Nenets autonomous territory]: a thesis. Tobol'sk, Tobol'skii ped. inst-t im. D. I. Mendeleeva. 73 p. (In Russ.).

Reshetov, A. M. (2002) Nikolai Nikolaevich Koz'min: osnovnye napravleniia nauchnoi deiatel'nosti [Nikolai Nikolaevich Koz'min: basic directions of research]. In: Repressirovannye etnografy [Ethnographers who fell victim of the Purges] / ed. by D. D. Tumarkin. Moscow, Vostochnaia literatura Publ. 343 p. Pp. 81-100. (In Russ.).

Romanova, E. N. (2003) G. V. Ksenofontov: mif o stranstvuiushchem geroe [G.V. Ksenofontov: a travelling hero myth]. In: Repressirovannye etnografy [Ethnographers who fell victim of the Purges] / ed. by D. D. Tumarkin. Moscow, Vostochnaia literatura Publ. Vol. 2. 495 p. Pp. 78-104. (In Russ.).

Rumiantsev, G. N. (1951) Rodoplemennoi sostav verkholenskikh buriat [Clan and tribal structure of Buryats of the Upper Lena]. In: Zapiski Buriat-mongol'skogo NII kul'tury. Vol. XII. Ulan-Ude, Burmongiz. 160 p. Pp. 78-108. (In Russ.).

Saaia, O. M., Badarch, B. and Dongak, A. S. (2018) Etnokul'turnye traditsii uriankhaitsev Mongolii (na materiale polevykh issledovanii) [Ethno-cultural traditions of the Mongolian Uriankhai: from field studies]. Aziia i Afrika segodnia, no. 10 (735), pp. 68-74. (In Russ.).

Sirina, A. A. (2002) Zabytye stranitsy sibirskoi etnografii: B. E. Petri [Forgotten pages of Siberian ethnography: B. E. Petri]. In: Repressirovannye etnografy [Ethnographers who fell victim of the Purges] / ed. by D. D. Tumarkin. Moscow, Vostochnaia literatura Publ. 343 p. Pp. 57-80. (In Russ.).

Skrynnikova, T. D. (1993) Etnotoponim Bargudzhin-Tokum [Bargudzhin-Tokum: an ethnotoponym] . In: Istoriia $i$ kul'tura narodov Tsentral'noi Azii [History and culture of the peoples of Central Asia] / ed. by Sh. V. Chimitdorzhiev. Ulan-Ude, BNTs SO RAN Publ. 138 p. Pp. 41-49. (In Russ.).

Spathari, N. G. (1882) Puteshestvie cherez Sibir' ot Tobol'ska do Nerchinska i granits Kitaia russkogo poslannika Nikolaia Spafariia v 1675 godu. Dorozhnyi dnevnik Spafariia [A journey through Siberia from Tobolsk to Nerchinsk and the borders of China by the Russian envoy Nikolai Spathari in 1675. Spathari's travel diary]. St. Petersburg, V. Kirshbaum,. 214 p. (In Russ.)

Spathari, N. G. (1960) Sibir' i Kitai [Siberia and China]. Kishinev, Kartya Moldovenyaske Publishers. 514 p. (In Russ.).

Sravnitel'no-istoricheskaia grammatika tiurkskikh iazykov. Regional'nye rekonstruktsii [A comparative historical grammar of Turkic languages] (2002) / ed. by E. R. Tenishev. Moscow, Nauka. 767 p. (In Russ.).

Tiurkskie narody Vostochnoi Sibiri [Turkic peoples of the Eastern Siberia] (2008) / ed. by D. A. Funk and N. A. Alekseev. Moscow, Nauka. 422 p. (In Russ.). 
НОВЫЕ ИССЛЕДОВАНИЯ ТУВЫ

www.nit.tuva.asia

Ushnitskii, V. V. (2010) Problema proiskhozhdeniia etnonima uriankhai [The origin of the ethnonym Uriankhai]. Gumanitarnye nauki v Sibiri, no. 4, pp. 96-99. (In Russ.).

Ushnitskii, V. V. (2011) Istoriografiia etnogeneza Sakha: obzor nauchnykh gipotez i versii [Historiography of the Sakha ethnogenesis: a review of hypotheses and versions in the field]. Vestnik NGU Seriia filologiia, filosofiia, vol. 10, issue 5. Arkheologiia i etnografiia, pp. 73-81. (In Russ.).

Ushnitskii, V. V. (2013) Naselenie Baikal'skogo regiona v epokhu srednevekov'ia (k probleme etnogeneza Sakha) [The population of the Baikal region in the Middle ages: on the ethnogenesis of the Sakha]. Yakutsk, IGIiPMNS SB of the RAS Publ. 173 p. (In Russ.).

Khomich, L. V. (1954) Nenetsko-russkii slovar' [A Nenets-Russian dictionary]. Leningrad, Uchpedgiz Publ.122 p. (In Russ.).

Tsibikdorzhiev, D. V. (1996) K voprosu o proiskhozhdenii etnonima kurykan [On the origin of the ethnonym Kurykan]. In: Gumanitarnye issledovaniia molodykh uchenykh Buriatii [Studies in the humanities by young scholars of Buryatia] : a collection of articles / Iangutov L. E. (ed.) et al. Ulan-Ude, BION. 199 p. Pp. 143-148. (In Russ.).

Chuluun, S. and Dongak, A. S. (2015) Etnokul'turnye kontakty narodov Saiano-Altaia i Zapadnoi Mongolii [Ethnocultural contacts between the peoples of Sayano-Altai and Western Mongolia]. The New Research of Tuva, no. 1 [online] Available at: https://nit.tuva.asia/nit/article/view/54 (access date: 01.02.2019). (In Russ.).

Shirobokova, N. N. (2005) Otnoshenie iakutskogo iazyka k tiurkskim iazykam Iuzhnoi Sibiri [The relations between the Yakut language and the Turkic languages of Southern Siberia]. Novosibirsk, Nauka. 269 p. (In Russ.).

Shirobokova, N. N. (2015) O smene klassifikatsionnogo tipa (na materiale tiurkskikh iazykov Sibiri) [On the change of classification type: the case of Turkic languages of Siberia]. Sibirskii filologicheskii zhurnal, no. 4, pp. 242-250. (In Russ.).

Iavorskaia, V. N. (2002) Kratkii toponimicheskii slovar' kazakhskikh geograficheskikh nazvanii i russkikh geograficheskikh terminov [A concise toponymical dictionary of Kazakh placenames and Russian geographic terms]. Petropavlovsk, North Kazakhstan University Publishers. 27 p. (In Russ.).

Janhunen, J. (2018) Ob etnonimakh oroki i uriankhai [On the ethnonyms Oroki and Uriankhai]. Rossiia i ATR, no. 4, pp. 11-24. (In Russ.).

Janhunen, J. (2014) On the ethnonyms Orok and Uriankhai. Studia Etymologica Cracoviensia, vol. 19, pp. 71-81.

Submission date: 12.03 .2019 . 